\title{
The human follicle stimulating hormone (hFSH) keeps the normal ultrastructure of caprine preantral follicles cultured in vitro
}

\author{
O hormônio folículo estimulante humano (hFSH) mantém a \\ ultraestrutura normal de folículos pré-antrais caprinos cultivados in \\ vitro
}

\author{
Sanely Lourenço da Costa ${ }^{1 *}$; Eduardo Paulino da Costa ${ }^{2}$; \\ Emílio César Martins Pereira ${ }^{3}$; Laércio dos Anjos Benjamin²; \\ Isabel Bezerra Lima Verde ${ }^{4}$; Juliana Jales de Hollanda Celestino ${ }^{5}$; \\ José Ricardo de Figueiredo ${ }^{6}$
}

\begin{abstract}
The aim of this study was to investigate the effects of human follicle stimulating hormone (hFSH) on the in vitro culture of caprine preantral follicles. Fragments of goat ovarian cortex were cultured in $\alpha-\mathrm{MEM}^{+}$ supplemented with 0,10 , or $50 \mathrm{ng} / \mathrm{mL}$ hFSH for one or seven days. Small fragments of non-cultured and cultured ovarian tissue were processed for classic histology and transmission electron microscopy. The statistical tests used in this study were Lilliefors, Cochran, and Tukey's (when significance was detected, PROC ANOVA, SAS was used). The results revealed a reduction in the percentage of normal follicles after one or seven days of culture under all treatment conditions. The rates of follicular survival were similar to each other, within each day of culture. The medium containing $10 \mathrm{ng} / \mathrm{mL} \mathrm{hFSH}$ reduced the percentage of primordial follicles following culture for one and seven days and did not increase the percentage of developing follicles. The follicular diameter of ovarian tissue cultured in $\alpha-\mathrm{MEM}^{+}$ medium and medium supplemented with $10 \mathrm{ng} / \mathrm{mL}$ of $\mathrm{hFSH}$ did not change when compared with the control (non-cultured). The ultrastructural analysis confirmed the integrity of follicles cultured for seven days in medium containing $10 \mathrm{ng} / \mathrm{mL} \mathrm{hFSH}$. In conclusion, $\mathrm{hFSH}(10 \mathrm{ng} / \mathrm{mL})$ is capable of promoting the activation of primordial follicles and maintaining the ultrastructural integrity of caprine preantral follicles cultured in vitro for seven days.
\end{abstract}

Key words: Caprine, preantral follicles, $\mathrm{hFSH}$, feasibility

\section{Resumo}

O objetivo desse estudo foi investigar os efeitos do FSH humano (hFSH) no cultivo in vitro de folículos pré-antrais caprinos. Fragmentos do córtex ovariano de caprinos foram cultivados em $\alpha$-MEM ${ }^{+}$ suplementado com 0,10 , ou $50 \mathrm{ng} / \mathrm{mL}$ de $\mathrm{hFSH}$ por um ou sete dias. Pequenos fragmentos de tecido ovariano cultivado e não cultivados, foram processados por histologia clássica e microscopia eletrônica

${ }^{1}$ Discente, Universidade Federal de Viçosa, UFV, Viçosa, MG, Brasil. E-mail: sanelylc@hotmail.com

2 Profs., UFV, Viçosa, MG, Brasil. E-mail: epcosta@ufv.br; laercio@ufv.br

3 Discente, UFV, Viçosa, MG, Brasil. E-mail: emiliovet2004@yahoo.com.br

${ }^{4}$ Prof $^{\mathrm{a}}$, Universidade Tiradentes, UNIT, Aracaju, SE, Brasil. E-mail: isabel_limaverde@yahoo.com.br

${ }^{5}$ Prof $^{\mathrm{a}}$, Universidade da Integração Internacional da Lusofonia Afro-Brasileira, UNILAB, Acarape, CE, Brasil. E-mail: juliana_ jales@yahoo.com.br

${ }^{6}$ Prof., Universidade Estadual do Ceará, UECE, Fortaleza, CE. Brasil. E-mail: jrfig@pesquisador.cnpq.br

* Author for correspondence 
de transmissão. Os testes estatísticos utilizados na pesquisa foram Lilliefors, Cochran, e Tukey's (caso significância - PROC ANOVA; SAS). Os resultados mostraram uma redução no percentual de folículos normais, após um ou sete dias de cultivo em todas as condições de tratamento. As taxas de sobrevivência folicular foram semelhantes entre si, dentro de cada dia de cultivo. O meio contendo $10 \mathrm{ng} / \mathrm{mL}$ de hFSH reduziu a percentagem de folículos primordiais no dia um e sete de cultivo, e não aumentou a percentagem dos folículos em desenvolvimento. $\mathrm{O}$ diâmetro folicular de tecido ovariano cultivado em meio $\alpha$-MEM ${ }^{+}$e meio suplementado com $10 \mathrm{ng} / \mathrm{mL}$ de $\mathrm{hFSH}$ não alterou, quando comparado com o controle (não cultivado). As análises ultraestruturais confirmaram a integridade de folículos cultivados por sete dias em meio contendo $10 \mathrm{ng} / \mathrm{mL}$ de $\mathrm{hFSH}$. Em conclusão, o hFSH (10 ng/mL) é capaz de promover a ativação de folículos primordiais e manter a integridade ultraestrutural de folículos préantrais caprinos cultivados in vitro por até sete dias.

Palavras-chave: Caprino, folículos pré-antrais, $\mathrm{hFSH}$, viabilidade

\section{Introduction}

Mechanisms that control the initiation of ovarian follicular development, that is, the activation of primordial follicles that are quiescent in the ovary, remain unclear, as does the time necessary for their growth and differentiation (FORTUNE et al., 2003). It has been established that follicular development is a complex process that is regulated by several autocrine, paracrine, and endocrine factors in the ovary (VAN DEN HURK; ZHAO, 2005). The follicle stimulating hormone (FSH) is one of the most important endocrine factors. FSH is a heterodimeric glycoprotein that is synthesized and secreted by gonadotropic cells present in the anterior portion of the pituitary (HAFEZ; HAFEZ, 2004; BERNARD et al., 2010). There are several ways of extracting FSH. Human FSH is extracted from the pituitary gland (hFSH) of women, from the urine of postmenopausal women, as a constituent of human menopausal gonadotropin (hMG), from highly purified urinary FSH (FSHu), and as pituitary extracts from domestic animals such as swine (pFSH) and sheep (oFSH). In addition, recent studies have used recombinant DNA technology, such as hamster ovary cells, to produce recombinant FSH (rFSH) (CALDER et al., 2003).

Some studies using molecular biology techniques have confirmed the expression of FSH receptors in swine granulosa cells (ULLOA-AGUIRRE et al., 2003), swine oocytes (MÉDURI et al., 2002), and human follicles, in which FSH receptors were observed in follicles with a layer of cubic granulosa cells (OKTAY et al., 1997), suggesting that FSH may have an effect on the growth of preantral follicles (SARAIVA et al., 2008).

In vitro culture of preantral follicles showed that the addition of FSH to the culture medium inhibits apoptosis (ALAM et al., 2009) of large secondary follicles isolated from different species, such as mouse (McGEE et al., 1997), human (WRIGHT et al., 1999), sheep (CECCONI et al., 1999), cow (GUTIERREZ et al., 2000), and pig (MAO et al., 2002). A recent study confirmed the efficacy of porcine FSH in the maintenance of morphological integrity, and the promotion of caprine preantral follicle activation and growth following culture for seven days (MATOS et al., 2007a; MAGALHÃES et al., 2009a). However, despite several FSH sources as the porcine and ovine have already been used for the follicular development of domestic species, little is known about the in vitro effects of human FSH in goats. Promising results from the in vitro culture of caprine preantral follicles, suggests that FSH may have some important characteristics related to the economic importance of this species in the production of milk, meat, and skin, which provide an important protein source for the population of the tropics (RAHMAN et al., 2008). Therefore, the aim of the present study was to investigate the effect of human FSH on the survival, activation, and growth of caprine preantral follicles during in vitro culture of ovarian tissue. 


\section{Materials and Methods}

\section{Source of ovaries}

Ovaries $(\mathrm{n}=16)$ of eight non-pregnant adult goats (one to three years of age) with body condition score (BCS) of around three were collected from a local slaughterhouse. Immediately postmortem, the ovaries were washed in $70 \%$ alcohol for $10 \mathrm{~s}$ and then washed again in minimum essential medium (MEM) supplemented with $100 \mu \mathrm{g} / \mathrm{mL}$ penicillin and $100 \mu \mathrm{g} / \mathrm{mL}$ streptomycin. Pairs of ovaries were transported to the laboratory in MEM at $4^{\circ} \mathrm{C}$ within $1 \mathrm{~h}$ postmortem (CHAVES et al., 2008). Unless otherwise stated, human FSH and other chemicals used in the present study were purchased from Sigma Chemical Co. (St Louis, USA).

\section{Experimental protocol}

In the laboratory, the ovaries were stripped of surrounding fat and fibrous tissue, and the ovarian cortex was recovered, placed in MEM supplemented with 4-(2-hydroxyethyl)-1piperazineethanesulfonic acid (HEPES) and divided into seven pieces of approximately $3 \times 3$ $\mathrm{mm}$ (1-mm thick) in size using a needle and scalpel under sterile conditions. For each animal, one slice of tissue was randomly selected and immediately fixed for histological and ultrastructural analyses (fresh control: day 0). The remaining slices of ovarian cortex were cultured individually in $1 \mathrm{~mL}$ culture medium in 24-well tissue culture dishes and incubated at $39^{\circ} \mathrm{C}$ in an atmosphere of $5 \%$ $\mathrm{CO}_{2}$. The basic control medium, hereafter referred to as $\alpha-\mathrm{MEM}^{+}$, consisted of $\alpha$-MEM ( $\mathrm{pH} 7.2-$ 7.4) supplemented with ITS (insulin $10 \mu \mathrm{g} / \mathrm{mL}$, transferrin $5.5 \mu \mathrm{g} / \mathrm{mL}$, and selenium $5 \mathrm{ng} / \mathrm{mL}$ ), 2 $\mathrm{mM}$ glutamine, $2 \mathrm{mM}$ hypoxanthine, and $1.25 \mathrm{mg}$ / $\mathrm{mL}$ bovine serum albumin (BSA). The medium was supplemented with human FSH at different concentrations $(0,10$, or $50 \mathrm{ng} / \mathrm{mL})$. Ovarian slices from each animal were cultured for 1 or 7 days and each treatment was repeated eight times. The culture media was stabilized at $39^{\circ} \mathrm{C}$ for $1 \mathrm{~h}$ prior to use and was replenished every second day in the tissue cultures.

Morphological analysis and assessment of in vitro follicular growth

Fresh control and cultured tissues were fixed in Carnoy's solution for $4 \mathrm{~h}$ and then dehydrated in increasing concentrations of ethanol. After paraffin embedding (Vetec, Rio de Janeiro, Brazil), the wax blocks containing the caprine tissue were completely and serially sectioned (7 $\mu \mathrm{m}$ sections), mounted on individual glass slides, and stained with Periodic Acid Schiff-hematoxylin (PAS staining system; Sigma). Follicle stage and survival were assessed microscopically using serial sections. The slides were examined under a microscope (Olympus, Japan) at $100 \times$ and $400 \times$ magnification by a single observer. Care was taken to only count each follicle once, consistent with our earlier studies (MATOS et al., 2007b). Each follicle was examined in every section and matched with the same follicle on adjacent serial sections in order to avoid double counting, thus ensuring that each follicle was only counted once regardless of its size.

The developmental stages of follicles have been defined previously (SILVA et al., 2004) as primordial (one layer of flattened granulosa cells around the oocyte) or developing follicles. Developing follicles can be subdivided into intermediate (both flattened and cuboidal granulose cells around the oocyte), primary (a single layer of cuboidal granulosa cells around the oocyte), and secondary (two or more layers of cuboidal granulosa cells around the oocyte). In the current study, follicles were individually classified as histologically normal even when an intact oocyte was present, the follicle was surrounded by granulosa cells that were well organized in one or more layers, and no pyknotic nucleus was observed (Fig. 1A). Atretic (degenerated) follicles were defined as those with a retracted oocyte, pyknotic nucleus, 
and/or disorganized granulosa cells detached from the basement membrane (Figure 1B). Overall, 240 preantral follicles were evaluated for each treatment (30 follicles per treatment for one repetition $\times$ eight repetitions $=240$ follicles). The percentages of healthy primordial and developing follicles were calculated on day 0 (fresh control) and after culture with each concentration of hFSH.

Figure 1. Histological sections of ovarian fragments after Periodic Acid Schiff- hematoxylin staining showing morphologically normal (A) and degenerated (B) follicles after culture with $50 \mathrm{ng} / \mathrm{mL} \mathrm{hFSH}$ for 7 days. O: oocyte; Nu: oocyte nucleus; GC: granulosa cell (Original magnification 400×). Scale bars represent $25 \mu \mathrm{m}$.

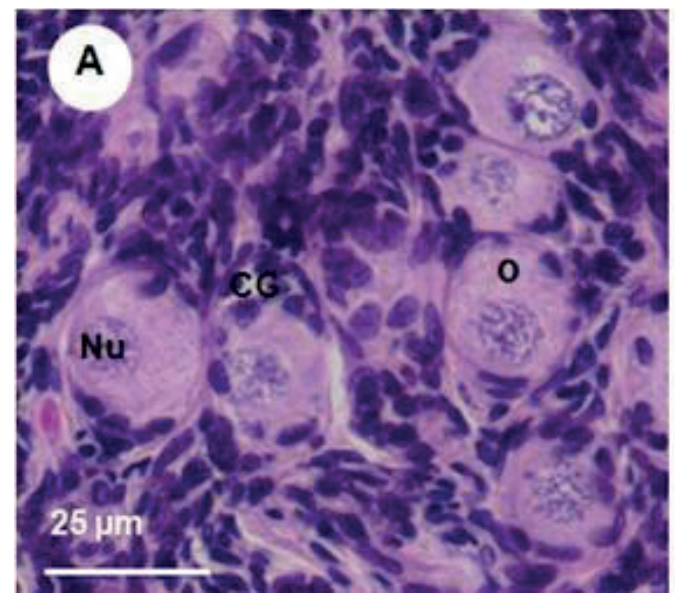

To evaluate follicular activation and growth, only intact follicles with a visible oocyte nucleus were recorded, and the proportions of primordial and growing follicles were calculated at day 0 (fresh control) and after 1 or 7 days of culture under the conditions tested. In addition, using only normal follicles, major and minor axes of each oocyte and follicle were measured using a light microscope fitted with an eyepiece micrometer (Zeiss, Cologne, Germany) under $400 \times$ magnification. The average of these two measurements was used to determine the diameters of each oocyte and follicle.

\section{Ultrastructural analysis of caprine preantral follicles}

For better evaluation of follicular morphology, ultrastructural studies were conducted on fragments of fresh control tissues and tissues from which the best results were obtained from histological

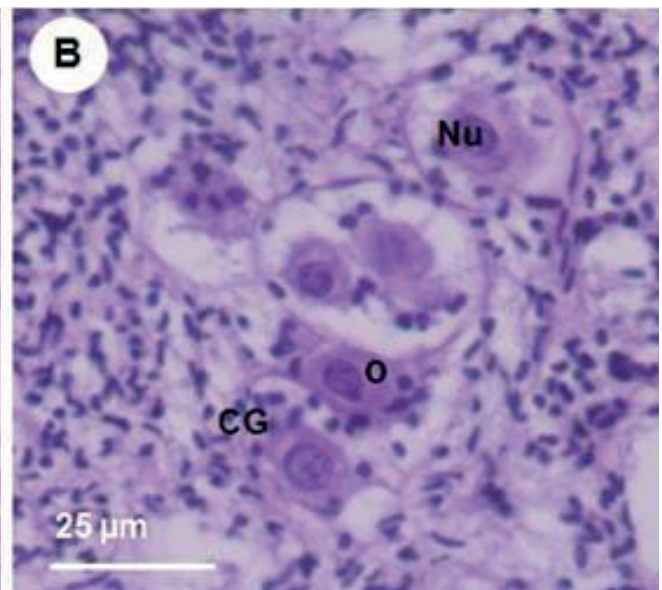

analysis after 1 and 7 days of culture. Briefly, $1-\mathrm{mm}^{3}$ pieces of goat ovarian tissue were fixed in $2 \%$ paraformaldehyde and $2.5 \%$ glutaraldehyde in $0.1 \mathrm{M}$ sodium cacodylate buffer $(\mathrm{pH} 7.2)$ for $4 \mathrm{~h}$ at room temperature. After fixation, fragments were post-fixed in $1 \%$ osmium tetroxide, and in $0.1 \mathrm{M}$ sodium cacodylate buffer for $1 \mathrm{~h}$. Subsequently, the samples were dehydrated through an acetone gradient, and the tissues were embedded in Epon 812 resin. For light microscopy studies, sections of 3- $\mu \mathrm{m}$ thickness were cut on an ultramicrotome (MT2-B, Sorvall, USA) and stained with toluidine blue. Ultra-thin sections of $60-70 \mathrm{~nm}$ thickness were contrasted with uranyl acetate and lead citrate and examined under an EM 109 Zeiss (EM, Berlin, Germany) transmission electron microscope (TEM). The density and integrity of ooplasmic and granulosa cell organelles, as well as vacuolization and basement membrane integrity, were evaluated. 


\section{Statistical analysis}

The variables were submitted to normality (Lilliefors) and homoscedasticity (Cochran) tests and posteriorly to analysis of variance at a probability of $5 \%$. When a significance was presented, Tukey's test was performed (PROC ANOVA; SAS, 2002).

\section{Results}

\section{Effect of human FSH on goat follicular survival}

A total of 1,680 preantral follicles were analyzed in the present study using classic histology. The percentages of morphologically normal follicles in fresh control tissue (non-cultured tissue) and after one or seven days of in vitro culture, in the absence or presence of $\mathrm{hFSH}$, are presented in Table 1. At the end of the culture period, a reduction $(\mathrm{P}<0.05)$ in the percentage of normal follicles in all treatment groups was observed compared to the fresh control (93.8\%). However, there was no difference ( $\mathrm{P}>$ $0.05)$ in the percentage of morphologically normal preantral follicles in any of the different treatment groups $(0,10$, and $50 \mathrm{ng} / \mathrm{mL}$ of human $\mathrm{FSH})$ following one $(80.4,80.8$, and $78.8 \%$, respectively) and seven days $(77.5,72.1$, and $72.1 \%$, respectively) of culture. During the progression of in vitro culture, there was a reduction $(\mathrm{P}<0.05)$ in the percentage of normal preantral follicles observed following treatment with 10 and $50 \mathrm{ng} / \mathrm{mL}$ of hFSH for 1 and 7 days (80.8 and $78.8 \%$ versus 72.1 and $72.1 \%$ respectively). This was not observed in follicles cultured in media without hFSH, in which the percentage of normal follicles on day seven $(77.5 \%)$ was similar to that observed on day one $(80.4 \%)(\mathrm{P}$ $<0.05)$.
Table 1. Percentage (mean \pm SEM) of morphologically normal preantral follicles in the fresh control (noncultured) and after in vitro culture for one or seven days in the absence or presence of hFSH (concentrations in $\mathrm{ng} / \mathrm{mL}$ ).

\begin{tabular}{|c|c|c|}
\hline Control & $93.8 \pm 1.0$ & \\
\hline & \multicolumn{2}{|c|}{ Normal } \\
\hline Treatments & Day 1 & Day 7 \\
\hline hFSH 0 & $80.4 \pm 4.2^{* \mathrm{aA}}$ & $77.5 \pm 2.1^{* \mathrm{aA}}$ \\
\hline hFSH 10 & $80.8 \pm 1.5^{* \mathrm{aA}}$ & $72.1 \pm 1.7^{* a \mathrm{~B}}$ \\
\hline hFSH 50 & $78.8 \pm 2.1^{*_{\mathrm{aA}}}$ & $72.1 \pm 1.8^{*} \mathrm{aB}$ \\
\hline
\end{tabular}

*Differs significantly from control follicles $(\mathrm{P}<0.05)$; ${ }^{\mathrm{a}, \mathrm{b}}$ differs significantly among concentrations in each day of culture $(\mathrm{P}<$ $0.05) ; \mathrm{A}, \mathrm{B}$ differs significantly with the progression of the culture period from day 1 to 7 in the same treatment group $(\mathrm{P}<0.05)$.

Activation of caprine primordial follicles after in vitro culture

The percentages of normal primordial and developing follicles in fresh tissue, or following one or seven days under different culture conditions are presented in Figure 2. The fresh ovarian tissues contained predominantly primordial follicles (55.4\%) and also presented developing follicles $(38.3 \%)$. There was a reduction (Figure 2, $\mathrm{P}<0.05$ ) in the percentage of primordial follicles after one day of culture in the presence of hFSH at $10 \mathrm{ng} / \mathrm{mL}$ (35.8\%) compared with the fresh control (55.4\%). This was same as that observed in the other treatment groups after seven days of culture (36.3, 20.8 , and $28.3 \%$ for 0,10 , and $50 \mathrm{ng} / \mathrm{mL}$ of $\mathrm{hFSH}$, respectively). However, in terms of the percentage of developing follicles, no difference (Figure 2, $\mathrm{P}$ $<0.05)$ between treatments $(40.8,45.0$, and $37.1 \%$, and $41.3,51.3$, and $43.8 \%$ for 0,10 , and $50 \mathrm{ng} /$ $\mathrm{mL}$ of $\mathrm{hFSH}$ on days one and seven, respectively) was observed when compared to the fresh control $(38.3 \%)$. 
Figure 2. Percentage (mean $\pm \mathrm{SEM}$ ) of (A) primordial and (B) developing follicles (intermediate, primary, and secondary) in non-cultured tissues (fresh control) and in tissues cultured for 1 or 7 days in the absence or presence of $\mathrm{hFSH}$ (concentrations in $\mathrm{ng} / \mathrm{mL}$ ). " Differs significantly from control follicles $(\mathrm{P}<0.05)$; ${ }^{\mathrm{a}, \mathrm{b}}$ differs significantly among concentrations in each day of culture $(\mathrm{P}<0.05) ; \mathrm{A}, \mathrm{B}$ differs significantly with the progression of the culture period from day 1 to 7 in the same treatment group $(\mathrm{P}<0.05)$.

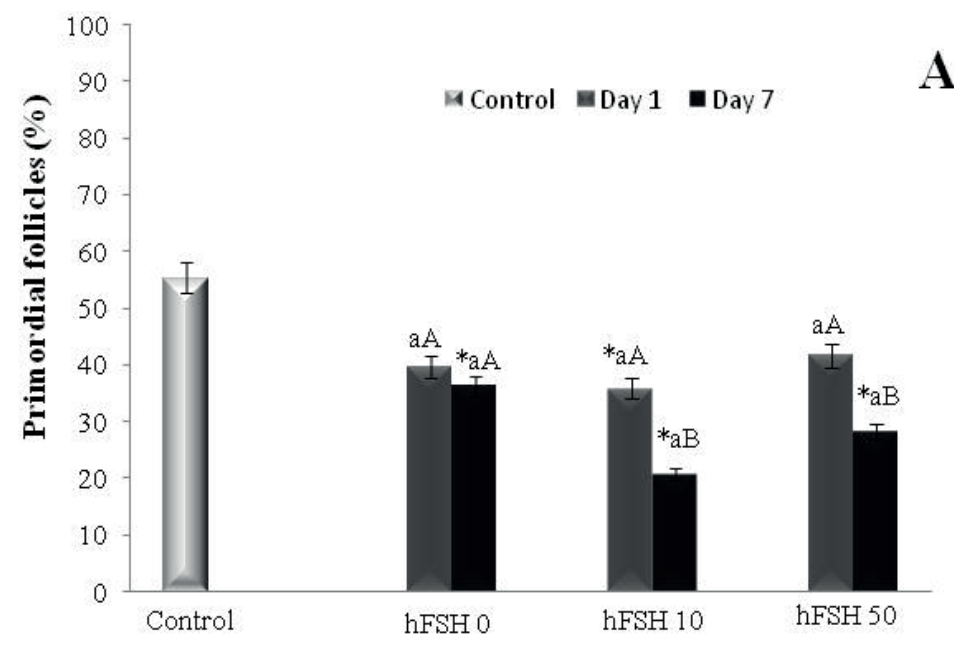

Treatm ents

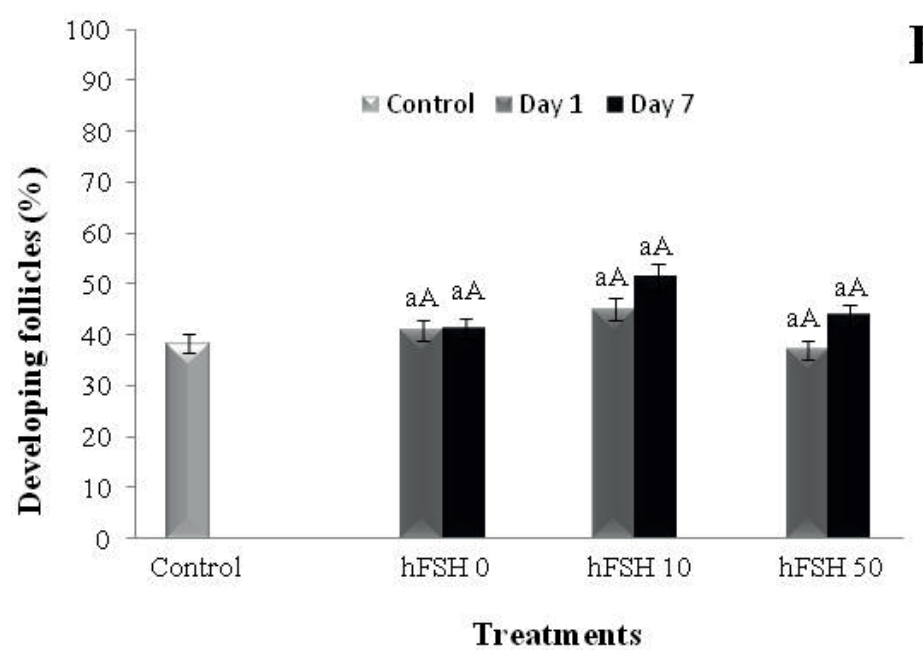

The addition of human FSH to tissues in vitro did not affect the percentage of primordial and developing follicles when compared to the tissues cultured in medium without hFSH $(\mathrm{P}>0.05)$. A decrease in the percentage of primordial follicles in the tissues cultured with 10 and $50 \mathrm{ng} / \mathrm{mL} \mathrm{hFSH}$ was observed as the culture period progressed from one to seven days (35.8 to $20.8 \%$ and 41.7 to $28.3 \%$ for 10 and $50 \mathrm{ng} / \mathrm{mL}$ of hFSH, respectively) (Figure 2, $\mathrm{P}<0.05$ ). However, as was observed for the developing follicles, no difference $(\mathrm{P}>0.05)$ was observed across the different treatment groups (Figure 2).

Evaluation of oocyte and follicular cell diameters in fresh and cultured tissues

The oocyte and follicular cell diameters were measured and are presented in Table 2. In relation to oocyte diameter, a reduction $(\mathrm{P}<0.05)$ in size 
was observed after one $(25.6,27.2$, and $20.0 \mu \mathrm{m}$ for 0,10 , and $50 \mathrm{ng} / \mathrm{mL}$ of $\mathrm{hFSH}$, respectively) and seven days $(25.5,25.4$, and $18.6 \mu \mathrm{m}$ for 0,10 , and $50 \mathrm{ng} / \mathrm{mL}$ of $\mathrm{hFSH}$, respectively) of culture in all the treatments, when compared to the non-cultured control $(29.6 \mu \mathrm{m})$. This decrease in oocyte diameter was higher $(\mathrm{P}<0.05)$ in tissues cultured with 50 $\mathrm{ng} / \mathrm{mL}$ of $\mathrm{hFSH}$, when compared to the other treatments. This reduction was more accentuated (P $<0.05)$ in the follicles cultured for seven days with $50 \mathrm{ng} / \mathrm{mL}$ of $\mathrm{hFSH}$.

Table 2. Diameters of caprine oocytes and follicles (mean \pm SEM) in non-cultured tissues (fresh control) and in tissues cultured for 1 or 7 days in the absence or presence of $\mathrm{hFSH}$ (concentrations in $\mathrm{ng} / \mathrm{mL}$ ).

\begin{tabular}{lcccc}
\hline & \multicolumn{2}{c}{ Oocyte diameter $(\mu \mathrm{m})$} & \multicolumn{2}{c}{ Follicle diameter $(\mu \mathrm{m})$} \\
\hline Control & \multicolumn{2}{c}{$29.6 \pm 0.8$} & Day 1 & Day 7 \\
\hline Treatments & Day 1 & Day 7 & $35.2 \pm 1.0^{\mathrm{aA}}$ & $35.3 \pm 1.6^{\mathrm{aA}}$ \\
\hline hFSH 0 & $25.6 \pm 0.7^{\mathrm{aA}_{\mathrm{A}}}$ & $25.5 \pm 0.8^{\mathrm{aA}_{\mathrm{A}}}$ & $38.2 \pm 1.0^{\mathrm{aA}}$ & $34.3 \pm 1.1^{\mathrm{aB}}$ \\
hFSH 10 & $27.2 \pm 0.7^{* \mathrm{aA}}$ & $25.4 \pm 0.6^{*_{\mathrm{aA}}}$ & $27.5 \pm 0.7^{* \mathrm{bA}}$ & $23.7 \pm 0.5^{* \mathrm{bB}}$ \\
\hline
\end{tabular}

*Differs significantly from control follicles $(\mathrm{P}<0.05)$; a,b differs significantly among concentrations in each day of culture $(\mathrm{P}<$ $0.05) ;{ }^{\mathrm{A}, \mathrm{B}}$ differs significantly with the progression of the culture period from day 1 to 7 in the same treatment $(\mathrm{P}<0.05)$.

Tissues cultured in medium with $50 \mathrm{ng} / \mathrm{mL}$ of hFSH exhibited a reduction $(\mathrm{P}<0.05)$ in the follicular cell diameter, after one $(27.5 \mu \mathrm{m})$ and seven days $(23.7 \mu \mathrm{m})$ when compared to the fresh tissue control $(37.9 \mu \mathrm{m})$ and the other treatment groups (35.2, $38.2 \mu \mathrm{m}$ and 35.3, $34.3 \mu \mathrm{m}$ for 0 and $10 \mathrm{ng} / \mathrm{mL}$ of $\mathrm{hFSH}$ on day one and seven, respectively). With the progression of the culture period, addition of hFSH (10 and $50 \mathrm{ng} / \mathrm{mL}$ ) led to a reduction $(\mathrm{P}<0.05)$ in follicular diameter $(38.2$ versus $34.3 \mu \mathrm{m}$ to $\mathrm{hFSH} 10 \mathrm{ng} / \mathrm{mL}$ and 27.5 versus $23.7 \mu \mathrm{m}$ to $\mathrm{hFSH} 50 \mathrm{ng} / \mathrm{ml})$, being the diameter maintained in the treatment in which hFSH (0 ng/ $\mathrm{mL}$ ) was not added.

\section{Ultrastructural features of cultured follicles}

Ultrastructural analysis was performed on noncultured tissues (control, day 0, Figure 3A) and in tissues cultured with $10 \mathrm{ng} / \mathrm{mL}$ of hFSH (Figure 3B) for seven days. The ultrastructural features of the follicles from the fresh control tissue or from tissues cultured for seven days with $10 \mathrm{ng} / \mathrm{mL}$ of $\mathrm{hFSH}$ were similar and exhibited intact oocytes, as well as basement and nuclear membranes (Figure 3A and $3 \mathrm{~B}$, respectively) and decondensed chromatin (Figure 3A). Furthermore, the follicles exhibited uniformly distributed organelles in the cytoplasm, especially endoplasmic reticula and mitochondria. The ultrastructure of granulosa cells was normal and well organized around the oocyte, revealing a large and elongated nucleus. 
Figure 3. Ultrastructural analysis (A) of a non-cultured preantral follicle (control; original magnification 4400x); and (B) a follicle cultured for 7 days in medium containing $10 \mathrm{ng} / \mathrm{mL} \mathrm{hFSH}$ (original magnification 4400x). Note the large nucleus of the granulosa cells in the control follicles and follicles cultured in the presence of $10 \mathrm{ng} / \mathrm{mL}$ hFSH. O: oocyte; Nu: oocyte nucleus; GC: granulosa cells; m: mitochondria; arrow-oocyte plasma membrane. (A and $\mathrm{B}=5 \mu \mathrm{m})$.
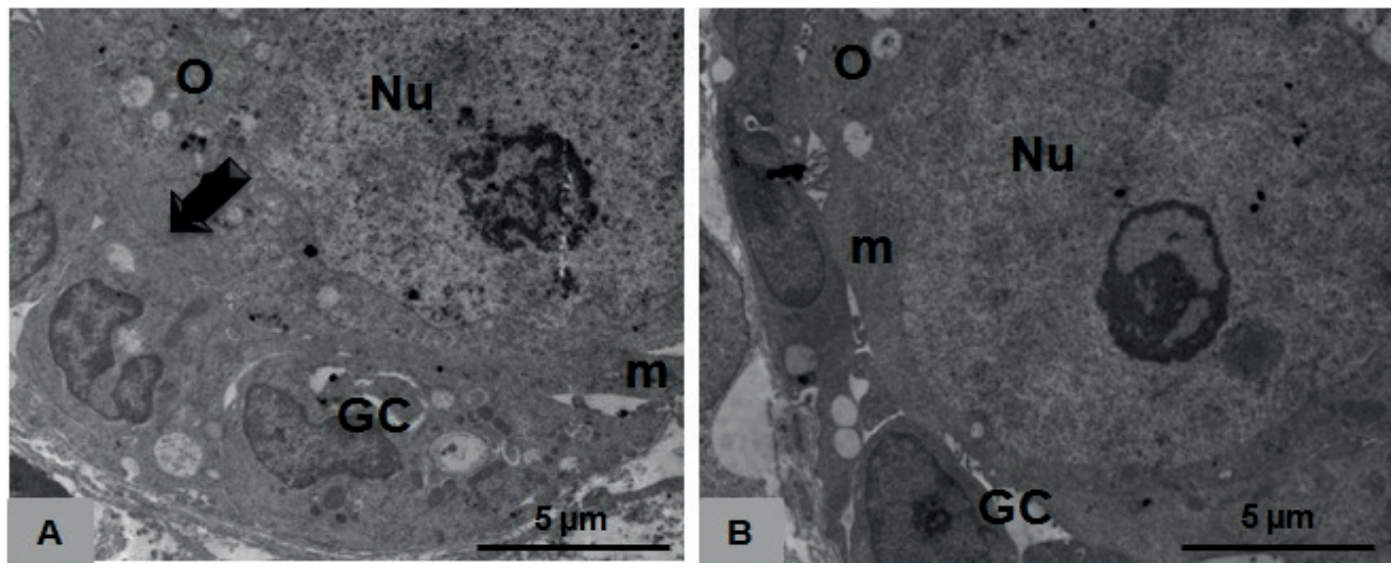

\section{Discussion}

Many studies have been conducted to elucidate the hormonal mechanisms that control ovarian development. However, more recently, attention has been directed to the substances that might be tested and used to identify the pathways that regulate folliculogenesis in its initial stage and promote a suitable microenvironment for ovarian development, thereby contributing to the reproductive competence of the host animal. However, few studies have been conducted using the addition of human FSH to in vitro culture media in animal research. In this study, two different human FSH concentrations (10 and $50 \mathrm{ng} / \mathrm{mL}$ ) were used during one and seven days of culture, to evaluate the influence of this hormone on the survival and in vitro growth of goat preantral follicles. Previously, porcine and recombinant FSH were used in in vitro culture by Matos et al. (2007a) and Magalhães et al. (2009a), respectively, to evaluate the influence of FSH on the survival and in vitro growth of goat preantral follicles.

As the culture period progressed from one to seven days, the $\alpha-\mathrm{MEM}^{+}$media without hFSH maintained the percentage of normal follicles in the culture. It is known that the media composition is important for the success of in vitro preantral follicle culture.

The $\alpha$-MEM ${ }^{+}$used in the present study is one of the richest MEM formulas. It contains 21 essential amino acids, vitamin $\mathrm{B}$ complexes, vitamins $\mathrm{C}$ and $\mathrm{D}$, inorganic salts, and pyruvate. This medium was also supplemented with glutamine, hypoxanthine, BSA, and ITS. According to Silva et al. (2004), the addition of hypoxanthine and energy substrates such as glutamine and pyruvate, as well as BSA and ITS to the base culture medium (in this case, MEM) significantly increases follicular cell survival in vitro (DEMEESTERE et al., 2005). Additionally, the reduced percentage of normal follicles in the presence of hFSH as the culture time progressed may have occurred due to the type ofFSH used. This hormone is obtained from human pituitary, which may be contaminated with traces of LH activity, with $15-20 \%$ possible contamination (BARROS; NOGUEIRA, 2005; BARUSELLI et al., 2006).

One of the most relevant factors that affect hormone bioactivity is the degree of purity obtained during its preparation (BOUSFIELD et al., 2008). $\alpha-\mathrm{MEM}^{+}$medium without $\mathrm{hFSH}$ was able to maintain the percentage of normal follicles until day seven of culture. According to Magalhães et al. (2009a), the higher the purity of the hormone (recombinant FSH), the better the efficiency of the 
hormone at maintaining the viability of the preantral follicle after culture. This suggests that the isoforms are influenced by the presence or absence of other proteins, such as LH. It has been reported that $\mathrm{LH}$ associated with $\mathrm{FSH}$ results in the degeneration of caprine preantral follicles cultured in vitro, with numerous vacuoles observed in the cytoplasm (SARAIVA et al., 2008). These vacuoles are the first signs of degeneration that can be observed in atretic follicles (CAMBONI et al., 2005), and might represent a dilated endoplasmic reticulum or altered mitochondrial development (CHAVES et al., 2010a; JORIO et al., 1991). The presence of $15-20 \%$ LH in the FSH composition may explain why treatment with 10 and $50 \mathrm{ng} / \mathrm{mL}$ of FSH could not maintain the survival of preantral follicles up to seven days of culture.

LH is indispensable for the final growth of follicles and for the complete maturation of oocytes in the antral phase (MELO et al., 2004). However, its role in the initial phase (preantral follicles) is not clearly defined (SALVETTI et al., 2007). Consistent with the results in the present study, researchers showed that swine FSH induces the degeneration of small bovine preantral follicles (NUTTINCK et al., 1996). Moreover, Silva et al. (2004) did not observe a significant effect of $\mathrm{pFSH}$ on follicular survival after five days of culture.

Regarding the follicular activation (that is, the transition from primordial to developing follicles (MCLAUGHLIN; MCIVER, 2009), the addition of $10 \mathrm{ng} / \mathrm{mL} \mathrm{hFSH}$ from one day of culture led to a decrease in the percentage of primordial follicles compared to the fresh control. These results are consistent with those previously obtained in in vitro studies with goats (MAGALHÃES et al., 2009b), in which the addition of $10 \mathrm{ng} / \mathrm{mL}$ of Folltropin was able to provide sufficient rates of activation on day one of culture. Another study also conducted by Magalhães et al. (2009a) showed that the addition of $10 \mathrm{ng} / \mathrm{mL}$ recombinant $\mathrm{FSH}$ and $10 \mathrm{ng} / \mathrm{mL}$ of swine FSH stimulated follicular activation for one and seven days of culture. In this study, it was also verified that, with the progression of the culture from one to seven days, the addition of FSH to the culture medium at 10 or $50 \mathrm{ng} / \mathrm{mL}$, led to a decrease in the percentage of primordial follicles, which was not observed when the $\alpha-\mathrm{MEM}^{+}$base medium did not contain hFSH. However, no difference between the developing follicles from the fresh control tissue and those from the different treatment groups was observed. Studies indicate that FSH can act directly in the follicle by binding to its receptor in the granulosa cells (O'SHAUGHNESSY et al., 1996; SALAS et al., 2006), or indirectly (VAN DEN HURK; ZHAO, 2005), through the stimulation of growth factors, such as Kit Ligand (KL), Bone Morphogenetic Protein-15 (BMP-15), and Growth and Differentiation Factor-9 (GDF-9), which are essential for follicular activation and development (CELESTINO et al., 2010).

Comparing the results at day seven of culture, a decrease in the number of primordial follicles might be expected, with a consequent increase in the number of developing follicles. However, this was not observed in the present study. According to Nuttinck et al. (1996), the addition of FSH to the culture medium increased the rate of oocyte degeneration in small bovine preantral follicles during seven days of culture. However, this was not observed by Derrar et al. (2000) following addition of $5 \mathrm{ng} / \mathrm{mL}$ of $\mathrm{FSH}$, or by Rodrigues et al. (2010) when adding FSH in the presence of $10 \%$ fetal bovine serum. Furthermore, Fortune et al. (1998) failed to observe a negative effect following the addition of 1,10 , or $100 \mathrm{ng} / \mathrm{mL}$ of FSH to the culture medium (SARAIVA et al., 2011).

In the present study, culture in the different media did not lead to an increase in the oocyte cell diameter, even after seven days. Furthermore, the medium containing $50 \mathrm{ng} / \mathrm{mL} \mathrm{hFSH}$ resulted in cells with a lower diameter when compared to that observed in the other treatment groups. A decrease in the diameter with the progress of culture from one to seven days also occurred. It is likely that this occurred due to the degeneration of oocytes 
in preantral follicles during the culture period, since in the preantral phase, even under adequate culture conditions, the oocyte is more resistant to degeneration than are the granulosa cells (SILVA et al., 2002).

In addition, Joyce et al. (1999) reported that FSH stimulates the expression of KL mRNA in granulosa cells of mouse preantral follicles cultured in vitro for $48 \mathrm{~h}$. KL is essential for oocyte growth (EPPIG, 2001; NILSSON; SKINNER, 2004) during the initial stages of follicular development (KLINGER; FELICI, 2002; HUTT et al., 2006). However, for oocyte growth to occur, KL must be in contact with the granulosa cells (THOMAS; VANDERHYDEN, 2006), and the effect of KL is modulated by the presence of gap junctions (KLINGER; FELICI, 2002; KEZELE et al., 2005) according to the phase of oocyte development. A possible explanation to account for no oocyte growth in the present study is that the FSH may not have stimulated KL mRNA, and therefore KL to allow this to occur. We believe that the lack of effect of human FSH on oocyte growth was due to the deficiency of some substance that is usually produced by the ovary and is required to generate a signal that allows follicular development to occur. Under the conditions of the culture system, this substance may be absent or its expression may be changed, and as a result, there was no increase in oocyte size (EPPIG, 2001).

The addition of hFSH (10 and $50 \mathrm{ng} / \mathrm{mL}$ ) to the culture medium led to a reduction in follicular diameter (Table 2) with the progression of culture from one to seven days. Moreover, the diameter of follicles following seven days of culture was lower than that observed in the control, with the addition of $50 \mathrm{ng} / \mathrm{mL}$ of $\mathrm{hFSH}$ to the medium. These results differ from those observed by Magalhães et al. (2009a) and Matos et al. (2007a), who reported an increase in the growth of goat follicles and oocytes cultured for seven days with $50 \mathrm{ng} / \mathrm{mL}$ recombinant $\mathrm{FSH}(\mathrm{rFSH})$ and $50 \mathrm{ng} / \mathrm{mL}$ porcine $\mathrm{FSH}$, respectively. Other authors demonstrated that rFSH increased the diameter of follicular and oocyte cells from cattle after 13 days of culture (ITOH et al., 2002). In addition, it was reported that the expression of FSH receptors (VAN DEN HURK; ZHAO, 2005) progressively increased during the transition from primordial to primary and secondary follicles (OKTAY et al., 1997). Méduri et al. (2002) detected the presence of FSH receptors in oocytes from porcine and human follicles. Since there are FSH receptors in oocytes, it is possible that FSH has to act in both cell types to promote follicular development and growth (MÉDURI et al., 2002).

Previous studies have reported that FSH can increase the diameter of human preantral follicles in culture (FORTUNE et al., 2004), suggesting that this hormone has an antiapoptotic and mitogenic effect (WRIGHT et al., 1999). Considering the temperature and gaseous atmosphere that are essential for successful culture, the reduction in follicular and oocyte cell diameter that was observed in the present experiment may be due to the culture medium used, which may not have been adequate to maintain the survival of larger preantral follicles. Consequently, as only the morphologically normal follicles were considered for the diameter evaluation, the reduced number of larger follicles by the end of the culture period led to a decrease in the average value for this parameter. Thus, in contrast to that observed in human oocytes and granulosa cells, we believe that FSH receptors present in goat oocytes and granulosa cells are not able to promote the increase of follicular diameter, although these receptors have not been quantified.

Several studies have demonstrated that TEM analysis following culture of preantral follicles, is an important tool to increase knowledge of the ultrastructural features of follicles (ZHAO et al., 2000; CHAVES et al., 2010a). This is because it reveals more information about the quality of follicles and oocytes (LOPES et al., 2009) and can detect damage to cell membranes and organelles (LUCCI et al., 2001; SALEHNIA et al., 2002). In this study, TEM revealed that the follicles cultured for seven days in $\alpha-\mathrm{MEM}^{+}$with $10 \mathrm{ng} / \mathrm{mL} \mathrm{hFSH}$ had 
a normal ultrastructure, which confirms the results observed by light microscopy. Using the TEM, it was observed that only the fresh control tissues and those cultured for seven days in the presence of $10 \mathrm{ng} / \mathrm{mL}$ $\mathrm{hFSH}$ were preserved. Thereby, it was observed that mitochondria, endoplasmic reticula, and granulosa cells were intact, as well as the basal membranes and nuclear envelope. The normal follicles in this study showed an ultrastructure similar to the caprine follicles previously described (LUCCI et al., 2001; CHAVES et al., 2010b), as well as bovine and ovine follicles (CRAN et al., 1980).

\section{Conclusions}

This study, using caprine preantral follicles enclosed in ovarian tissue, showed that $\mathrm{hFSH}$ at a concentration of $10 \mathrm{ng} / \mathrm{mL}$ can promote the activation of primordial follicles. Moreover, these results demonstrate that $\mathrm{hFSH}$ has a vital role in maintaining the ultrastructural integrity of caprine preantral follicles cultured for up to seven days in vitro.

\section{Acknowledgments}

To CNPq for providing financial support for this research. To CAPES for providing the Doctorate scholarship. To the core staff of Microscopy and Microanalysis of UFV for their support in the ultrastructural analysis.

\section{References}

ALAM, H.; WECK, J.; MAIZELS, E.; PARK, Y.; LEE, E. J.; ASHCROFT, M.; HUNZICKER-DUNN, M. Role of the phosphatidylinositol-3-kinase and extracellular regulated kinase pathways in the induction of hypoxiainducible factor (HIF)-1 activity and the HIF-1 target vascular endothelial growth factor in ovarian granulose cells in response to follicle-stimulating hormone. Endocrinology, Washington, v. 150, n. 2, p. 915-928, 2009.

BARROS, C. M.; NOGUEIRA, M. F. G. Superovulation in zebu cattle: protocol P-36. Embryo Transfer NewsLetter, Champaign, v. 23, n. 2, p. 5-9, 2005.
BARUSELLI, P. S.; SÁ FILHO, M. F.; MARTINS, C. M.; NASSER, L. F.; NOGUEIRA, M. F. G.; BARROS, C. M.; BÓ, G. A. Superovulation and embryo transfer in Bos indicus cattle. Theriogenology, New York, v. 65, n. 1, p. 77-88, 2006.

BERNARD, D. J.; FORTIN, J.; WANG, Y.; LAMBA, P. Mechanisms of FSH synthesis: what we know, what we don't, and why you should care. Fertility and Sterility, Birmingham, v. 93, n. 8, p. 2465-2485, 2010.

BOUSFIELD, G. R.; BUTNEV, V. Y.; BIDART, J. M.; DALPATHADO, D.; IRUNGU, J.; DESAIRE, H. Chromatofocusing fails to separate $\mathrm{hFSH}$ isoforms on the basis of glycan structure. Biochemistry, Washington, v. 47, n. 6, p. 1708-1720, 2008.

CALDER, M. D.; CAVENEY, A. N.; SMITH, L. C.; WATSON, A. J. Responsiveness of bovine cumulusoocyte-complexes (COC) to porcine and recombinant human $\mathrm{FSH}$, and the effect of COC quality on gonadotropin receptor and $\mathrm{Cx} 43$ marker gene mRNAs during maturation in vitro. Reproductive Biology and Endocrinology, Londres, v. 14, n. 14, p. 1-12, 2003.

CAMBONI, A.; MARTINEZ-MADRID, B.; DOLMANS, M.; MACCHIARELLI, G.; DONNEZ, J.; NOTTOLA, S. A. Contribution of transmission electron microscopy to the study of human ovarian tissue integrity after enzymatic isolation, cryopreservation or xenografting. Fertility and Sterility, Birmingham, v. 84, n. 1, p. S104, 2005.

CECCONI, S.; BARBONI, B.; COCCIA, M.; MATTIOLI, M. In vitro development of sheep preantral follicles. Biology of Reproduction, Madison, v. 60, n. 3, p. 594-601, 1999.

CELESTINO, J. J. H.; BRUNO, J. B.; LIMA-VERDE, I. B.; MATOS, M. H.; SARAIVA, M. V.; CHAVES, R. N.; MARTINS, F. S.; ALMEIDA A. P.; CUNHA, R. M.; LIMA, L. F.; NAME, K. P.; CAMPELLO, C. C.; SILVA, J. R.; BÁO, S. N.; FIGUEIREDO, J. R. Steady-state level of Kit Ligand mRNA in goat ovaries and the role of Kit Ligand in preantral follicle survival and growth in vitro. Molecular Reproduction Development, Malden, v. 77, n. 3, p. 231-240, 2010.

CHAVES, R. N.; ALVES, A. M. C. V.; DUARTE, A. B. G.; ARAÚJO, V. R.; CELESTINO, J. J. H.; MATOS, M. H. T.; LOPES, C. A. P.; CAMPELLO, C. C.; NAME, K. P. O.; BÁO, S. N.; FIGUEIREDO, J. R. Nerve growth factor promotes the survival of goat preantral follicles cultured in vitro. Cells Tissues Organs, Atlanta, v. 192, n. 4, p. 272-282, 2010a.

CHAVES, R. N.; LIMA-VERDE, I. B.; CELESTINO, J. J. H.; DUARTE, A. B. G.; ALVES, A. M. C. V.; MATOS, 
M. H. T.; CAMPELLO, C. C.; NAME, K. P. O.; BÁO, S. N.; BURATINI JÚNIOR, J.; FIGUEIREDO, J. R. Fibroblast growth factor -10 maintains the survival and promotes the growth of cultured goat preantral follicles. Domestic Animal Endocrinology, New York, v. 39, n. 4, p. 249-258, 2010b.

CHAVES, R. N.; MARTINS, F. S.; SARAIVA, M. V.; CELESTINO, J. J.; LOPES, C. A.; CORREIA, J. C.; VERDE, I. B.; MATOS, M. H.; BÁO, S. N.; NAME, K. P.; CAMPELLO, C. C.; SILVA, J. R. V.; FIGUEIREDO, J. R. Chilling ovarian fragments during transportation improves viability and growth of goat preantral follicles cultured in vitro. Reproduction Fertility and Development, Collingwood, v. 20, n. 5, p. 640-647, 2008.

CRAN, D. G.; MOOR, R. M.; HAY, M. F. Fine structure of the sheep oocyte during antral follicle development. Journals of Reproduction \& Fertility, Cambridge, v. 59, n. 1, p. $125-132,1980$.

DEMEESTERE, I.; CENTNER, J.; GERVY, Y.; DELBAERE, A. Impact of various endocrine and paracrine factors on culture of preantral follicles in rodents. Reproduction, Bradley Stoke, v. 130, n. 2, p. 147-156, 2005 .

DERRAR, N.; PRICE, C. A.; SIRARD, M. A. Effect of growth factors and co-culture with ovarian medulla on the activation of primordial follicles in explants of bovine ovarian cortex. Theriogenology, New York, v. 54, n. 4, p. 587-598, 2000.

EPPIG, J. J. Oocyte control of ovarian follicular development and function in mammals. Reproduction, Bradley Stoke, v. 122, n. 6, p. 829-838, 2001.

FORTUNE, J. E. The early stages of follicular development: activation of primordial follicles and growth of preantral follicles. Animal Reproduction Science, Philadelphia, v. 78, n. 3, p. 135-163, 2003.

FORTUNE, J. E.; KITO, S.; WANDJI, A. S.; SRSEN, V. Activation of bovine and baboon primordial follicles in vitro. Theriogenology, New York, v. 49, n. 2, p. 441-449, 1998.

FORTUNE, J. E.; RIVERA, G. M.; YANG, M. Y. Follicular development: the role of the follicular microenvironment in selection of the dominant follicle. Animal Reproduction Science, Philadelphia, v. 82-83, n. x, p. 109-126, 2004.

GUTIERREZ, C. G.; RALPH, J. H.; TELFER, E. E.; WILMUT, I.; WEBB, R. Growth and antrum formation of bovine preantral follicles in long-term culture in vitro. Biology of Reproduction, Madison, v. 62, n. 5, p. 13221328, 2000.
HAFEZ, E.; HAFEZ, B. Reprodução animal. $7^{\text {th }}$ ed. Barueri: Mande, 2004. 513 p.

HUTT, K. J.; MCLAUGHLIN, E. A.; HOLLAND, M. K. KIT/KIT ligand in mammalian oogenesis and folliculogenesis: roles in rabbit and murine ovarian follicle activation and oocyte growth. Biology of Reproduction, Madison, v. 75, n. 3, p. 421-433, 2006.

ITOH, T.; KACCHI, M.; ABE, H.; SENDAI, Y.; HOSHI, $H$. Growth, antrum formation, and estradiol production of bovine preantral follicles cultured in a serum-free medium. Biology of Reproduction, Madison, v. 67, n. 4, p. 1099-1105, 2002.

JORIO, A.; MARIANA, J. C.; LAHLOU-KASSI, A. Development of the population of ovarian follicles during the prepubertal period in D'man and Timahdit shee. Journals of Reproduction \& Fertility, Cambridge, v. 26, n. x, p. 239-250, 1991.

JOYCE, I. M.; PENDOLA, F. L.; WIGGLESWORTH, K.; EPPIG, J. J. Oocyte regulation of Kit ligand expression in mouse ovarian follicles. Developmental Biology, Philadelphia, v. 214, n. x, p. 342-353, 1999.

KEZELE, P.; NILSSON, E. E.; SKINNER, M. K. Keratinocyte growth factor acts as a mesenchymal factor that promotes ovarian primordial to primary follicle transition. Biology of Reproduction, Madison, v. 73, n. 5, p. 967-973, 2005.

KLINGER, F. G.; FELICI, M. de. In vitro development of growing oocytes from fetal mouse oocytes: stagespecific regulation by stem cell factor and granulosa cells. Developmental Biology, Philadelphia, v. 244, n. 1, p. 85-95, 2002.

LOPES, C. A. P.; SANTOS, R. R.; CELESTINO, J. J. H.; MELO, M. A.; CHAVES, R. N.; CAMPELLO, C. C.; SILVA, J. R. V.; BÁO, S. N.; JEWGENOW, K.; FIGUEIREDO, J. R. Short-term preservation of canine preantral follicles: effects of temperature, medium and time. Animal Reproduction Science, Philadelphia, v. 115, n. 1-4, p. 201-214, 2009.

LUCCI, C. M.; SILVA, R. V.; CARVALHO, C. A.; FIGUEIREDO, J. R.; BÁO, S. N. Light microscopical and ultrastrutural characterization of goat preantral follicles. Small Ruminant Research, Philadelphia, v. 41, n. 1, p. 61-69, 2001.

MAGALHÃES, D. M.; ARAÚJO, V. R.; LIMAVERDE, I. B.; MATOS, M. H. T.; SILVA, R. C.; LUCCI, C. M.; BÁO, S. N.; CAMPELLO, C. C.; FIGUEIREDO, J. R. Different follicle-stimulating hormone (FSH) sources influence caprine preantral follicle viability and development in vitro. Brazilian Journal of Veterinary 
Research and Animal Science, São Paulo, v. 46, n. 5, p. 378-386, 2009a.

Impact of pituitary FSH purification on in vitro early folliculogenesis in goats. Biocell, Mendoza, v. 33, n. 2, p. 91-97, 2009(b).

MAO, J.; WU, G.; SMITH, M. F.; MCCAULEY, T. C.; CANTLEY, T. C.; PRATHER, R. S.; DIDION, B. A.; DAY, B. N. Effects of culture medium, serum type, and various concentrations of follicle-stimulating hormone on porcine preantral follicular development and antrum formation in vitro. Biology of Reproduction, Madison, v. 67, n. 4, p. 1197-1203, 2002.

MATOS, M. H. T.; LIMA-VERDE, I. B.; BRUNO, J. B.; LOPES, C. A. P.; MARTINS, F. S.; SANTOS, K. D. B.; ROCHA, R. M. P.; SILVA, J. R. V.; BÁO, S. N.; FIGUEIREDO, J. R. Follicle stimulating hormone and fibroblast growth factor-2 interact and promote goat primordial follicle development in vitro. Reproduction, Fertility and Development, Collingwood, v. 19, n. 5, p. 677-684, 2007b.

MATOS, M. H. T.; LIMA-VERDE, I. B.; LUQUE, M. C. A.; MAIA JÚNIOR, J. E.; SILVA, J. R. V.; CELESTINO, J. J. H.; MARTINS, F. S.; BÁO, S. N.; LUCCI, C. M.; FIGUEIREDO, J. R. Essential role of follicle stimulating hormone in the maintenance of caprine preantral follicle viability in vitro. Zygote, Cambridge, v. 15, n. 2, p. 173$182,2007 \mathrm{a}$.

McGEE, E. A.; SPEARS, N.; MINAMI, S.; HSU, S. Y.; CHUN, S. Y.; BILLIG, H.; HSUEH, A. J. W. Preantral ovarian follicles in serum-free culture: suppression of apoptosis after activation of the cyclic guanosine 3', $5^{\prime}$-monophosphate pathway and stimulation of growth and differentiation by follicle-stimulating hormone. Endocrinology, Washington, v. 138, n. 6, p. 2417-2424, 1997.

MCLAUGHLIN, E. A.; MCIVER, S. C. Awakening the oocyte: controlling primordial follicle development. Reproduction, Bradley Stoke, v. 137, n. 1, p. 1-11, 2009.

MÉDURI, G.; CHARNAUX, N.; DRIANCOURT, M. A.; COMBETTES, L.; GRANET, P.; VANNIER, B.; LOOSFELT, H.; MIGROM, E. Follicle-stimulating hormone receptors in oocytes? The Journal of Clinical Endocrinology \& Metabolism, Washington, v. 87, n. 5, p. 2266-2276, 2002.

MELO, D. S.; FERREIRA, M. M. G.; MONTEIRO, F. M.; NOGUEIRA, M. F. G.; TRINCA, L. A.; BARROS, C. M. Manutenção de níveis sub-luteais de progesterona, após tratamento superestimulatório, pode diminuir a taxa de recuperação de embriões. Acta Scientiae Veterinariae, Porto Alegre, v. 32, p. 1-22, 2004. Suplemento.
NILSSON, E. E.; SKINNER, M. K. Kit ligand and basic fibroblast growth factor interactions in the induction of ovarian primordial to primary follicle transition. Molecular and Cellular Endocrinology, Philadelphia, v. 214, n. 1-2, p. 19-25, 2004.

NUTTINCK, F.; COLLETE, L.; MASSIP, A.; DESSY, F. Histologic and autoradiographic study of the in vitro effects of FGF-2 and FSH on isolated bovine preantral follicles: preliminary investigations. Theriogenology, New York, v. 45, n. 6, p. 1235-1245, 1996.

OKTAY, K.; BRIGGS, D.; GOSDEN, R. G. Ontogeny of follicle-stimulating hormone receptor gene expression in solated human ovarian follicles. The Journal of Clinical Endocrinology \& Metabolism, Washington, v. 82, n. 11, p. 3748-3751, 1997.

O'SHAUGHNESSY, P. J.; DUDLEY, K.; RAJAPAKSHA, W. R Expression of follicle stimulating hormone-receptor mRNA during gonadal development. Molecular and Cellular Endocrinology, Philadelphia, v. 125, n. 1-2, p. 169-175, 1996.

RAHMAN, A. N. M. A.; ABDULLAH, R. B.; WAN KHADIJAH, W. E. A review of reproductive biotechnologies and their applications in goat. Journal of Biotechnology, Philadelphia, v. 7, n. 2, p. 371-384, 2008.

RODRIGUES, G. Q.; SILVA, C. M. G.; FAUSTINO, L. R.; BRUNO, J. B.; PINTO, L. C.; LOPES, C. A. P.; CAMPELlO, C. C.; FIGUEIREDO, J. R. Efeito de diferentes concentrações de hormônio Folículoestimulante recombinante sobre o desenvolvimento in vitro de folículos pré-antrais caprinos e ovinos isolados. Acta Veterinaria Brasilica, Mossoró, v. 4, n. 3, p. 144$152,2010$.

SALAS, C. M.; JULIO-PIEPER, M.; VALLADARES, M.; POMMER, R.; VEJA, M.; MASTRONARDI, C.; KERR, B.; OJEDA, S. R.; LARA, H. E.; ROMERO, C. Nerve growth factor-dependent activation of TrkA receptors in the human ovary results in synthesis of FSH receptors and estrogen secretion. The Journal of Clinical Endocrinology \& Metabolism, Washington, v. 91, n. 6, p. 2396-2403, 2006.

SALEHNIA, M.; MOGHADAN, E. A.; VELOJERDI, M. R. Ultrastructure of follicles after vitrification of mouse ovarian tissue. Fertility and Sterility, Birmingham, v. 78, n. 3, p. 644-645, 2002.

SALVETTI, P.; THEAU-CLÉMENT, M.; BECKERS, J. F.; HURTAUD, J.; GUÉRIN, P.; NETO, V.; FALIÈRES, J.; JOLY, T. Effect of the luteinizing hormone on embryo production in superovulated rabbit does. Theriogenology, New York, v. 67, n. x, p. 1185-1193, 2007. 
SARAIVA, M. V. A.; CELESTINO, J. J. H.; CHAVES, R. N.; MARTINS, F. S.; BRUNO, J. B.; LIMA-VERDE, I. B.; MATOS, M. H. T.; SILVA, G. M.; PORFIRIO, E. P.; BÁO, S. N.; CAMPELLO, C. C.; SILVA, J. R. V.; FIGUEIREDO, J. R. Influence of different concentrations of LH and FSH on caprine primordial ovarian follicle development in vitro. Small Ruminant Research, Philadelphia, v. 78, n. 1-3, p. 87-95, 2008.

SARAIVA, M. V. A.; ROSSETTO, R.; BRITO, I. R.; CELESTINO, J. J. H.; SILVA, C. M.; G.; FAUSTINO. L. R.; ALMEIDA, A. P.; BRUNO, J. B.; MAGALHÃES, D. M.; MATOS, M. H. T.; CAMPELlO, C. C.; FIGUEIREDO, J. R. Dynamic medium produces caprine impact of sequential culture medium on in vitro development of caprine preantral follicles. Zygote, Cambridge, v. 19, n. 3, p. 205-214, 2011.

STATISTICAL ANALYSIS SYSTEM INSTITUTE - SAS. SAS/STAT ${ }^{\circledR}$ 9. 0 User's guide. Cary, NC: SAS Institute Inc., 2002.

SILVA, J. R. V.; FERREIRA, M. A. L.; COSTA, S. H. F.; SANTOS, R. R.; CARVALHO, F. C. A.; RODRIGUES, A. P. R.; LUCCI, C. M.; BÁO, S. N.; FIGUEIREDO, J.

$R$. Degeneration rate of preantral follicles in the ovaries of goats. Small Ruminant Research, Philadelphia, v. 43, n. 3, p. 203-209, 2002.

SILVA, J. R. V.; VAN DEN HURK, R.; MATOS, M. H. T. M.; SANTOS, R. R.; PESSOA, C.; MORAES, M. O. de; FIGUEIREDO, J. R. Influences of FSH and EGF on primordial follicles during in vitro culture of caprine ovarian cortical tissue. Theriogenology, New York, v. 61, n. 9, p. 1691-1704, 2004.
THOMAS, F. H.; VANDERHYDEN, B. C. Oocytegranulosa cell interactions during mouse follicular development regulation of kit ligand expression and its role in oocyte growth. Reproductive Biology and Endocrinology, Londres, v. 19, n. 4, p. 1-8, 2006.

ULLOA-AGUIRRE, A.; TIMOSSI, C.; BARRIOS-DETOMASI, J.; MALDONADO, A.; NAYUDU, P. Impact of carbohydrate heterogeneity in function of FSH: studies derived from in vitro and in vivo models. Biology of Reproduction, Madison, v. 69, n. 2, p. 379-389, 2003.

VAN DEN HURK, R.; ZHAO, J. Formation of mammalian oocytes and their growth, differentiation and maturation within ovarian follicles. Theriogenology, New York, v. 63, n. 6, p. 1717-1751, 2005.

WRIGHT, C. S.; HOVATTA, O.; MARGARA, R.; TREW, G.; WINSTON, R. M. L.; FRANKS, S.; HARDY, $\mathrm{K}$. Effects of follicle-stimulating hormone and serum substitution on the in-vitro growth of human ovarian follicles. Human Reproduction, Oxford, v. 14, n. 6, p. 1555-1562, 1999.

ZHAO, J.; DORLAND, M.; TAVERNE, M. A. M.; VAN DER WEIJDEN, G. C.; BEVERS, M. M.; VAN DEN HURK, R. In vitro culture of rat pre-antral follicles with emphasis on follicular interactions. Molecular Reproduction Development, Malden, v. 55, n. 1, p. 6574, 2000. 